\title{
YESUS DAN MUHAMMAD PEMBAWA MISI KESELAMATAN: \\ Sebuah Analisa Teologis
}

\author{
Abdullah \\ Universitas Islam Negeri Alauddin Makassar \\ Abdullahdu1687@gmail.com
}

\begin{abstract}
Abstrak
Kehadiran dan kebenaran bukan pada Yesus atau Muhammad saw, tetapi kehadiran hanya sebatas penyampai dan peringatan bukan untuk menjadi Tuhan yang otoriter dan dipertuhankan oleh umat, karena ia hanya pancaran dan "perpanjangan tangan Tuhan" (agent of wisdom). Akan tetapi Kebenaran itu sendiri adalah bersumber dari pemberi kebenaran yakni Tuhan Allah swt atau dalam perspektif Katolik Ia adalah Elea Tuhan kita. Tulisan ini membahas tentang bagaimana titik sentuh secara aksiologi antara Katolik dengan Islam tentang keselamatan yang menjadi tujuan hidup manusia. Secara aksiologis tentang upaya aktualisasi kehidupan selamat di antara sesama manusia yang berbeda keyakinan dan keragaman budaya, merupakan unsur keindahan hidup yang senantiasa dirindukan oleh semua orang. Hanya saja perlu diketahui semua unsur manusia, dalam meningkatkan kehidupan yang damai sejahtera, aman dan tentram harus selalu melakukan introspeksi diri pada setiap umat baik yang menyangkut tentang diri, kelompok sosial keagamaaan, maupun budaya masing-masing.
\end{abstract}

\begin{abstract}
JESUS AND MUHAMMAD, THE CARRIERS OF SALVATION MISSION: A THEOLOGICAL ANALYSIS. The presence and the prophetic mission of Jesus or Muhammad PBUH actually is only as a transmitter and a warner, or, either simply as a missionary or an extension of the Lord (the agent of wisdom); Not a God or to be a God, as many people suppose. Truth itself is derived from the original truth of the Lord, God Almighty or in the Catholic perspective: He was Elea, our Lord. This paper discusses axiological touch points between the Catholic doctrine of Islam on the concept of salvation as the goal of human life. Axiologically, attempts to actualize the concept of salvation among people of different beliefs and cultures is one element
\end{abstract}


of the beauty of life that is always missed by everyone. However, in order to achieve a peaceful, prosperous, safe, and secure life, human have to realize that they should always do the painstaking efforts, individually and socially.

Kata Kunci: Kehadiran dan kebenaran Yesus-Muhammad dan misi keselamatan

\section{A. Pendahuluan}

Perjumpaan Islam dan Kristen pada persoalan keselamatan merupakan esoterisme kebenaran dan kehadiran. Alasannya bahwa keselamatan dari Yesus (Katolik) merupakan perwujudan dari Yang Maha Mutlak karena itu identik dengan Yang Mutlak. Di lain pihak bahwa perwujudan itu bersifat transenden dan selalu ada.

Dalam gnosis (ma'rifat) inilah Islam dan Kristen bertemu, sebab hati adalah al-Qur'an yang imanen atau nabi yang imanen, jika menekankan pada fungsi aktif dan inspirasional akal. Oleh karena itu, dalam Islam memiliki unsur Kehadiran diwakili oleh alQur'an dan Nabi. Konsekwensi logis dari unsur kebenaran tersebut merupakan titik tolak dalam Islam. Unsur kehadiran menjadi identik dengan sakramen dan ekaristi dalam al-Qur'an dan juga dengan nabi Muhammad. Proses filosofis dari ekaristi insaniyah ke dalam ontologi "cetakan" Muhammad sebagai "norma primordial”, yakni "fitrah". ${ }^{1}$ Al-Qur'an adalah kebenaran dan kehadiran sekaligus. Ia merupakan kebenaran karena doktrinnya, yang mengajarkan bahwa hanya ada satu Yang Mutlak. Ia merupakan kehadiran, karena sifat theophanic atau sakramentalnya sebagai objek dzikir dan doa.

Hakekat kehidupan kemanusiaan dan keumatan adalah memiliki kesadaran mendalam untuk menyebarkan substansi dari nilai-nilai kehadiran melalui al-Qur'an, tali kasih, dan cinta yang sepenuh hati di antara manusia. Islam mengajarkan kepada kita untuk menjalin hubungan silaturrahim dalam pengertian yang luas. Sedangkan dalam tradisi Katolik mengenal adanya doktrin yang mengatakan bahwa semua dunia adalah kasihmu maka sebarkanlah

\footnotetext{
${ }^{1}$ Cetakan dimaksud adalah melibatkan diri ke dalam Sunnah, kumpulan aturan-aturan yang diajarkan dan diamalkan oleh Nabi yaitu aturan horisontal dan vertikal yang mencakup dunia sosial, material dan kehidupan ruhaniah.
} 
rasa kasih dan cintamu kepada semua orang. Oleh karena itu, agama Yesus adalah agama sejati, yaitu pengalaman hidup pribadi Yesus dalam mencapai ke-Ilahian. Yesus begitu taat pada Bapa-Nya. Dia, yang walaupun adalah seorang pencipta, datang ke dunia dan memberikan contoh hidup yang ideal.

Tulisan ini ingin membicarakan tentang makna kehadiran Yesus, makna kehadiran atau kebenaran dan esoterik konsep tersebut. Selain itu, akan membahas juga tentang makna kehadiran Yesus sebagai mitra nabi Muhammad saw.

\section{B. Makna Kehadiran}

Kehadiran Yesus bukan untuk menyengsarakan, tapi Ia penerang segala kehidupan. Pengorbanan beliau ibarat lilin-lilin yang membakar dirinya demi menerangi jalan kehidupan yang dilalui seluruh alam beserta isinya. Hal ini sangat relevan dengan eksistensi Muhammad sebagai rahmat lil alamin, beliau dalam tasawuf Ibn Arabi disebutkan sebagai lambang kekamilan alam beserta isinya. Sehingga sering disebutkan sebagai cahaya yang bersenyawa di atas cahaya.

Menjadikan Yesus sebagai penyelamat dalam hidup dan kehidupan dengan benar-benar iman, karena Yesus itulah penebus yang dijanjikan Yahwe. ${ }^{2}$

Yahwe dalam Kristen sudah melakukan semuanya agar manusia layak dan suci untuk langsung masuk ke dalam Sorga-Nya. Inilah bukti bahwa Yahwe itu Maha Pengasih. Dia tidak ingin satu pun manusia masuk ke dalam neraka karena Dia tahu neraka adalah tempat penuh penyiksaan. Dia membeci dosa tapi mengasihi pendosa. Sedangkan Yahwe dalam Islam sama sekali tidak menunjukkan sifatNya yang Maha Pengasih karena Dia membiarkan manusia masuk dan mengalami siksaan di neraka. Dia tahu bahwa anda dengan usaha sendiri tidak akan layak untuk masuk ke tempat-Nya yang kudus, akan tetapi hanya saja pandangan atau keyakinan Kristen agak berbeda dengan keyakinan muslim tentang eksistensi Tuhan (Yahwe). Dalam perspektif sebagian besar Kristiani bahwa Yahwe

${ }^{2}$ Hanya melalui Yesus-lah setiap orang bisa kembali ke Firdaus, seperti kata Yesus: "Akulah jalan dan kebenaran dan hidup. Tidak ada seorangpun yang datang kepada Bapa, kalau tidak melalui Aku.” (Yoh.14:6). 
(Zat) tidak sama dengan Bapa (Roh). Anggapan ini mengingat sabda Yesus. ${ }^{3}$

Pemikiran seperti di atas, pada dasarnya tidak dapat dimunculkan dipermukaan, sebab sangat eksklusif. Pemikiran yang eksklusif kurang memberikan ruang toleransi dan dialog yang sehat, sebab dalam keyakinannya hanya agama dia yang benar, di luarnya serba salah. Oleh karena itu, keyakinan yang up to date adalah keyakinan dan pemikiran yang inklusif, karenanya sangat kaya akan keterbukaan dan keragaman agama, sosial, dan budaya.

Keyakinan para penganut suatu agama yang inklusif, sangat adaptatif dengan perubahan zaman yang semakin mengarah kepada pluralitas kehidupan yang serba multikulturalis. Karena itu, dalam Katolik pun memuat tentang pesan saling mengakui eksistensi kebenaran suatu agama lain. Bentuk pengakuan eksistensi Bibel sebagai kitab suci Katolik kepada agama bukan Katolik adalah telah meramalkan keberadaan Muhammad sebelum beliau hadir di permukaan bumi.

\section{Kehadiran atau Kebenaran}

Nabi Muhammad saw dan kaum muslimin awal percaya bahwa hadirnya Muhammad sebagai nabi telah dikabarkan di dalam Bibel. Al-Qur'an menyatakan bahwa Muhammad adalah nabi dan rasul "yang namanya telah didapati tertulis di dalam Taurat dan Alkitab” (QS. 7:157). Ada pula beberapa ayatyang menyebutkan orangorang Yahudi disalahkan karena menyembunyikan kebenaran atau menyembunyikan bagian dari ajaran-ajaran atau tidak menyatakan dengan sebenarnya. Ayat-ayat atau ajaran-ajaran yang disembunyikan itu pada awalnya mungkin dipahami sebagai menyembunyikan berita akan datangnya Muhammad sebagai seorang nabi dan rasul. Khalifah al Mahdi dalam sebutan Timothy menyebutkan, ada tiga ayat yang dengan tegas mengabarkan kenabian Muhammad. Satu ayat dalam Deuteronomy 18: 18 yang menyebutkan bahwa Allah menjanjikan kepada Bani Israel untuk mengirimkan seorang nabi seperti nabi Musa dari keturunan mereka. ${ }^{4}$

${ }^{3}$ Yesus mengatakan, "tidak seorang pun mengenal Bapa selain Anak dan orang yang kepadanya Anak itu berkenan menyatakannya.” (Matius 11:27).

${ }^{4}$ Ayat lain yang menyatakan "seorang penunggang unta dari Isaiah" (27:7), 
Umat Katolik memahami perkabaran akan hadirnya Paraclet atau Sang Juru Selamat ini sebagai petunjuk kepada Ruh Kudus, seperti yang secara eksplisit dinyatakan dalam Yoh 14: 26. Sungguhpun demikian, dalam beberapa hal ada kesamaan yang dicatat antara dua kata dari bahasa Yunani, periklutos, yang berarti "termasyhur" atau "patut dipuji" dan, parakletos atau paradete. Agaknya dua kata itulah yang menjadi landasan pernyataan bahwa apakah Yesus (Isa) benar-benar telah mengatakan tentang Paraclet secara sungguh-sungguh yang ditujukan kepada nabi Muhammad saw yang nama ini juga berarti "terpuji" atau "mulia."

Pada sisi ini, agaknya perlu kembali kepada al-Qur'an untuk melihat ayat yang penting sebagai berikut:

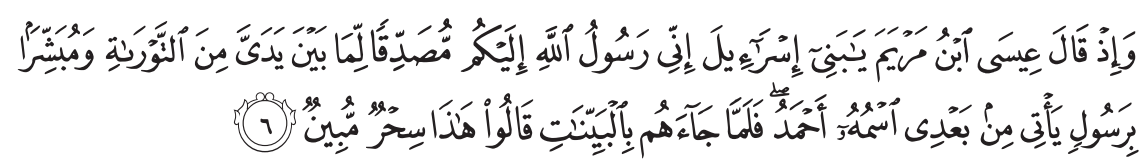

Dan (Ingatlah) ketika Isa ibnu Maryam berkata: "Hai Bani Israil, Sesungguhnya Aku adalah utusan Allah kepadamu, membenarkan Kitab sebelumku, yaitu Taurat, dan memberi khabar gembira dengan (datangnya) seorang Rasul yang akan datang sesudahku, yang namanya Ahmad (Muhammad)." Maka tatkala Rasul itu datang kepada mereka dengan membawa bukti-bukti yang nyata, mereka berkata: "Ini adalah sihir yang nyata." (QS. Shaaf: 6).

Ayat tersebut menjelaskan bahwa adanya keterbukaan nabi Isa (Yesus) menerima kebenaran atas kehadiran Ahmad (Muhammad) sebagai pelanjut risalah Tuhan. Meskipun secara historis, Muhammad adalah nabi yang hadir pasca Isa, namun Yesus tetap menghargai akan kehadirannya.

Sejak pertengahan abad ke delapan, kata -Ahmad- diambil sebagai nama sebenarnya yang menjadi alternatif terhadap kata Muhammad. Kendati pun demikian, semenjak saat itu kata Ahmad yang dianggap sebagai kata sifat yang berarti "Yang Terpuji", memang kata itu masih merujuk kepada kata Muhammad. Yang penting bahwa kira-kira tahun 781 Masehi, al-Mahdi memberi

yang dikatakan oleh para ahli pikir kontemporer bahwa ayat ini secara faktual menunjukkan jama' (plural); dan yang ketiga adalah janji Paraclet atau Sang Juru Selamat dalam kitab Perjanjian Baru. 
tahukan kepada Timothy agar tidak mengambil kata Ahmad sebagai sebuah nama yang sebenarnya. ${ }^{5}$

Berdasarkan realitas sejarah sampai abad ke-8, kata Ahmad pada ayat (QS.61:6) tersebut diambil sebagai kata sifat, yang didukung oleh berbagai fakta yang lain. Jadi, dalam biografinya tentang Muhammad, Ibn Ishaq (meninggal tahun $768 \mathrm{M}$ ), menyebutkan ayat ini dengan mengajukan pertanyaan, namun tidak menjelaskan nama Ahmad sebagai nama panggilan nabi Muhammad. ${ }^{6}$ Tentang ayat ini dapat dikatakan bahwa Ibn Ishaq membuat terjemahan secara bebas yang akurat dalam (Yoh: 15: 23, 16: 1), berbeda dengan pengubahan "Aku akan mengirim kamu dari Sang Bapa" dengan pernyataan "Allah akan mengirim kamu dari Tuhan." Terjemahan aktual dari Bibel ini sama sekali tidak biasa terjadi pada penulispenulis muslim. Dalam pengenalan kutipan, Ibn Ishaq menyatakan "apakah dari murid Yohanes dituliskan bagi mereka pada saat dia menulis kitab al-Kitab dari kesaksian ('ahd) Yesus putra Maria, mengenai Rasul Allah."7

Ibn Ishaq di tempat lain dan pada buku Tabaqat yang dikarang oleh Ibn Sa'ad (meninggal tahun $844 \mathrm{M}$ ), ada berbagai kisah tentang jalan orang-orang Yahudi dan orang-orang Katolik yang menyembunyikan ayat-ayat yang mengabarkan tentang kehadiran Muhammad sebagai nabi. Kadangkala ada penyembunyian fisik

${ }^{5}$ Fakta yang menghebohkan ini sampai kira-kira tahun 740 Masehi sehingga tidak ada nama orang Islam yang memakai nama Ahmad, akan tetapi setelah itu sebutan Ahmad menjadi amat umum sebagai nama panggilan alternatif terhadap kata Muhammad. Pernyataan ayat al-Qur'an tersebut menyatakan bahwa dalam lingkungan Muhammad ini ada kesadaran yang membingungkan antara periklutos dan parakletos; dan memang dalam tulisan bahasa Semit hanya menggunakan konsonan yang masing-masing identik benar-peraklitos. Lihat William Montgomery Watt, Titik Temu Islam dan Kristen Persepsi dan Salah Persepsi, Terj. Zaimudin, Cetakan 1, (Jakarta: Penerbit Gaya Media Pratama, 1996), h. 9.

${ }^{6}$ Ibid.

7 Menurut Ibn Ishaq, kutipan ini merupakan klaimnya bahwa terma manhamanna yang digunakan untuk gubahan makna "paraklet" (orang yang terpuji) pada ayat tersebut, adalah sebuah kata dari bahasa Syria yang berarti Muhammad dan ini merupakan ekuivalen dengan kata baraqlitis. Jika mungkin di luar tempat ini dapat mendiskusikan percabangan-percabangan bahasa Syria dalam argumen ini. Titik tekan yang harus dicatat bahwa kaum muslimin benar-benar yakin kalau Muhammad ini sungguh telah diramalkan di dalam kitab Bibel. 
dengan memotong halaman-halaman bersama sekaligus, atau dengan menghapus satu ayat atau mengganti satu ayat dengan ayat yang lain.

Kisah-kisah itu seluruhnya rupanya mengacu kepada penduduk bangsa yang ummi (buta huruf) yang masih berfikir sederhana. Kisah-kisah yang menyatakan bahwa orang-orang Yahudi membayangkan seorang nabi ini kemungkinan berasal dari bayangbayang seorang Messiah. Kisah yang paling terkenal adalah kisah pendeta Katolik, Bahira, yang waktu itu Muhammad sedang dalam perjalanan menuju Syria. Maka diketahui dari deskripsi bukubukunya yang mengisyaratkan kenabian antara kedua bahu pundak beliau dan memberitahukan kepada paman beliau, Abū Țālib, agar berhati-hati menjaga Muhammad.

Sejak abad ke delapan, sebagian ilmuwan muslim meneliti ayat-ayat Bibel lebih lanjut yang dapat diklaim meramalkan kehadiran Muhammad sebagai nabi atau rasul. Tak pelak lagi bahwa memang secara implisit menyatakan kekuatan teks Biblikal dan adanya kontradiksi bentuk-bentuk ajaran tersebut di mana seluruh teks itu tidak dapat dipercaya. Seorang ilmuwan yang tersohor, Ibn Qutaibah (meninggal tahun $889 \mathrm{M}$ ), menemukan kira-kira sejumlah ayat, namun orang ini didahului oleh seorang yang masuk Islam dari beragama Kristen Ali Ibn Rubban aț-Ṭabari ${ }^{8}$

Umat Kristen dewasa ini yang berfikir bahwa pesan nabi yang paling mendasar adalah untuk zaman dan tempat beliau sendiri. Hal ini tentu dipahami secara berbeda dengan umat Kristen di zaman-zaman Perjanjian Baru yang melihat pada pesan-pesan yang meramalkan masa depan. Dewasa ini umat Kristen memperkenankan bahwa pesan-pesan kenabian ini kemungkinan dapat menunjukkan masa depan dengan dua cara. Cara yang pertama, seorang nabi yang dapat memberi perhatian kepada orang-orang sezamannya dengan bencana-bencana yang menimpa mereka sebagai hukuman terhadap tingkah laku atau perbuatan dosa yang telah mereka lakukan. Semua bencana yang ditimpakan kepada mereka ini dibayangkan untuk hari depan yang dekat. Cara yang kedua, pesan-pesan kenabian dapat berisi pernyataan-pernyataan umum tentang jalan-jalan dimana

${ }^{8}$ Jangan dikacaukan dengan aț-Ṭabari sebagai ulama ahli tafsir dan ahli sejarah, yang menghasilkan tafsirnya tidak kurang dari 130 ayat. 
Tuhan berhadapan dengan makhluk yang bernama manusia, baik hukuman terhadap perbuatan dosa maupun memberi daya dorong agar tulus jujur dan membebaskan mereka dari kesengsaraan; dan tindakan-tindakan yang memberi dorongan yang diperlukan agar tidak segera terjadi.

Dalam kitab Ulangan Deuteronomy 18: 14-19, di mana Musa mengatakan kepada Bani Israel bahwa Tuhan akan menurunkan kepada mereka seorang nabi seperti dirinya dari antara bapakbapak mereka. Hal ini kiranya menyatakan prinsip umum, yakni ketika manusia yang beriman itu perlu petunjuk ketuhanan atau pertolongan Tuhan yang lain yang hendak mengirimkan seorang nabi kepada mereka. Prinsip ini dapat dikatakan telah terpenuhi pada keseluruhan rentetan nabi-nabi, yang memberi petunjuk kepada Bani Israel berabad-abad lamanya. Kemudian orang-orang Yahudi berfikir untuk mengaplikasikan pekabaran ini dengan hadirnya Sang Messiah, dan ini diberikan dalam artian umat Kristen awal dan ditujukan kepada Yesus (Kisah 3:22, dan seterusnya). ${ }^{9}$

Perlu dicatat di sini bahwa cara berfikir modern tentang kenabian, ternyata tidak menetapkan penyimpangan dengan persamaan-persamaan aksidental antara lembaran-lembaran kenabian dan peristiwa-peristiwa yang terjadi kemudian. Jadi ada sebuah ayat dalam Yesaya yang menyebutkan:

Tanda kekuasaan ini adalah perempuan muda yang akan menerima dan melahirkan seorang anaklelaki, dan akan memberikan namanya dengan Immanuel. Mentega dan madu yang hendak mereka makan, agar dia tahu bagaimana orang ini menghilangkan kejahatan dan memilih yang baik. Karena sebelum beliau mengetahui bahwa dia mengetahui bagaimana menghilangkan kejahatan dan memilih yang baik. Karena sebelum dia mengetahui bagaimana menghilangkan kejahatan dan memilih yang baik, karena sebelum dia mengetahui bagaimana dapat ditinggalkannya kejahatan dan

${ }^{9}$ Berdasarkan titik pandang ini, maka orang yang beragama Kristen dapat diakui bahwa mereka juga berlaku kepada Muhammad. Kendatipun demikian, pada waktu yang sama harus ditunjukkan bahwa dewasa ini umat Kristen tidak melihat terpenuhinya ramalan ini pada seseorang sebagai suatu bukti kenabiannya; baik dia ini benar-benar seorang nabi yang dikenal dari kualitas pesan-pesan yang disampaikannya maupun akibat pesan-pesan tersebut dalam kehidupan pemelukpemeluknya. 
dipilih yang engkau benci itu akan ditinggalkan oleh kedua rajanya (Yes. 7: 14).

Para ilmuwan modern juga memahami anak kalimat di atas secara berbeda satu dengan yang lain. Dalam versi Yunani kuno, satu kata pada ayat di atas mempunyai arti "perawan" atau "kesucian" walaupun dalam bahasa Yahudi berarti "gadis" atau perempuan muda yang belum kawin yang di satu saat nanti akan menuju jenjang perkawinan. Umat Kristen awal yang akrab dengan bahasa Yunani menyatakan bahwa ayat tersebut menunjukkan ramalan akan konsepsi keperawanan atau kesucian Yesus dan Immanuel dianggap sebagai salah satu namanya. ${ }^{10} \mathrm{Jadi}$, tentang aplikasi Kristen modern kepada Yesus ini tidak memberikan sesuatu bukti apapun, dalam artian tidak lebih dari kejadian yang luar biasa; namun mempunyai tempat sejarah yang kuat dalam sejarah Kristen karena merupakan bagian dari cara berfikir umat Kristen awal terdahulu. Dalam memberi tahukan kejadian ini, secara implisit menyatakan bahwa kejadian luar biasa itu bukan merupakan bagian dari titah Tuhan, dikarenakan nabi-nabi mengucapkan kalimat-kalimat yang samarsamar yang artinya hanya akan jelas pada abad-abad terkemudian.

Namun begitu, umat Kristen yakin bahwa hasrat dan kematian Yesus telah diramalkan di dalam Perjanjian Lama. Akan tetapi ramalan ini jatuh kedalam kategori pernyataan umum tentang bagaimana Tuhan menghadapi manusia secara individual maupun komunitas. Satu dari pernyataan tersebut adalah penjelasan tentang penderitaan hamba Tuhan dalam Yesaya 52: 13, 53: 12. Walaupun hal ini nampak secara khusus dipergunakan kepada Yesus sebagai Messiah, namun ada pengertian dimana tiap-tiap orang mengatakan keselamatan dan keselamatan bekerja yang penting bagi Tuhan. Karena itu barangkali harus menghadapi penderitaan dari kematian. Agaknya jelas untuk orang luar bahwa umat Islam dewasa ini berusaha keras untuk mencapai dukungan bagi apa yang mereka anggap sebagai konsep Islam yang lebih benar ketimbang

${ }^{10}$ Menurut pemahaman modern, ayat tersebut memberitahukan kepada raja di waktu itu, Ahaz, bahwa malapetaka akan mengiringi musuh-musuhnya dalam waktu beberapa tahun mendatang. Nama Immanuel atau "Tuhan bersama kita”, menekankan prinsip umum dan meyakinkan raja yang senantiasa berada pada jaminan pertolongan Tuhan terus-menerus. Akan tetapi ayat tersebut juga dipahami menunjuk kepada Yesus yang akan lahir 700 tahun kemudian. 
konsep-konsep kaum fundamentalis yang secara pasti hampir harus menghadapi penderitaan yang besar.

\section{Esoteristik konsepsi Kehadiran dan Kebenaran}

Pemikiran tentang keselamatan dari pandangan Karl Rahner dan Hans Küng (mewakili Katolik) dan Murțadā Muțahari dengan Sayyed Hosein Nașr (mewakili Islam) secara substansial, samasama meyakini bahwa sumber keselamatan datang dari Tuhan melalui usaha manusia. Lebih universal lagi bahwa keselamatan yang diinginkan dalam kehidupan di dunia ini adalah keselamatan personal, sosial dan hubungan kenegaraan secara internasional. Maksudnya keselamatan yang diperoleh dengan keharmonisan dalam hidup pribadi, bermasyarakat dan berbangsa. Usaha seperti itu, dapat dilakukan dengan meningkatkan pemahaman keagamaan yang bersifat inklusif. Pemahaman keagamaan yang inklusif sesuai dengan ajaran kitab suci setiap agama. Dalam ajaran Islam inklusifisme sebagaimana dijelaskan pada beberapa ayat dalam alQur'an di antaranya disebutkan dalam QS. 21:25;

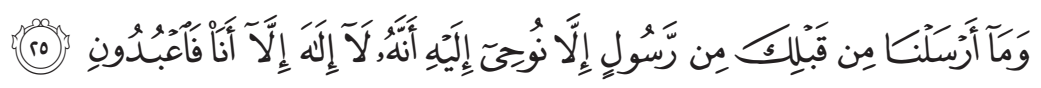

Dan Kami tidak mengutus seorang rasulpun sebelum kamu melainkan kami wahyukan kepadanya: "Bahwasanya tidak ada Tuhan (yang hak) melainkan aku, maka sembahlah olehmu sekalian akan aku”. (21:25). ${ }^{11}$

Kemudian pada ayat lain Allah swt menyebutkan dalam alQur'an Surat 21;92 bahwa :

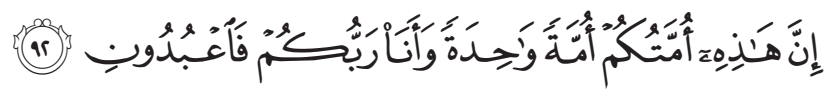

Sesungguhnya (agama Tauhid) Ini adalah agama kamu semua; agama yang satu dan Aku adalah Tuhanmu, Maka sembahlah Aku. $^{12}$

Atas dasar prinsip-prinsip yang dinyatakan dalam ayat-ayat tersebut di atas, Nurcholish menjelaskan bahwa disebabkan adanya

${ }^{11}$ Departemen Agama RI, al-Qur'an dan Terjemahannya (Semarang: Toha Putra, 1989), h. 498.

${ }^{12}$ Ibid., h. 507 
prinsip kemajemukan keagamaan itu (religius plurality) ${ }^{13}$, maka ajaran itu tidak perlu artikan sebagai secara langsung pengakuan akan kebenaran semua agama dalam bentuknya yang real pada kehidupan sehari-hari. Akan tetapi ajaran kemajemukan itu memudahkan pengertian dasar resiko yang akan ditanggung oleh pengikut agama masing-masing. Sikap ini ditafsirkan sebagai salah satu harapan kepada semua agama yang ada, yaitu disebabkan semua agama pada mulanya menganut prinsip yang sama. Bentuk persamaan di sini adalah keharusan manusia berpasrah pada Tuhan Yang Maha Esa.

Abdurrahman Wahid (Gus Dur) ${ }^{14}$, menulis sebuah buku yang berjudul Islamku, Islam Anda dan Islam Kita, sebuah judul yang diambil dari sebuah artikel bab I, "Islam dalam Diskursus Ideologi, Kultural dan Gerakan"15, yang akan diterjemahkan ke dalam tujuh bahasa dunia.

Oleh karena itu, secara universal agama Islam merupakan agama kemanusiaan dan kemakhlukan. Seseorang yang menginginkan keselamatan dalam ber-Islam, seharusnya bertindak yang berprikemanusiaan dan berprikemakhlukan. Tujuannya adalah untuk mencapai kesejateraan dalam hidup dan kehidupan. Keselamatan seseorang bukan dilihat dari segi kasih sayang Tuhan,

${ }^{13}$ Secara normatif doktriner, Islam dengan tegas memandang pluralisme sebagai suatu keniscayaan. Bukti normatif yang ditujukan Nurcholish Madjid adalah terdapatnya gagasan ahl al-Kitab dalam Al-Qur'an, yaitu konsep yang memberikan pengakuan kepada para penganut agama lain yang memiliki kitab suci. Ini bukan berarti memandang semua agama sama, sesuatu hal yang mustahil, mengingat kenyataan agama yang ada, berbeda-beda dalam banyak hal sampai kepada hal yang prinsip. Tetapi memandang pluralisme dalam pengakuan sebatas hak masing-masing untuk bereksistensi dengan kebebasan mengaturkan agama masing-masing.

${ }^{14}$ Gus Dur lahir di Denanyar Jombang Jawa Timur, tanggal 4 Agustus 1946. Beliau lahir dari keluarga ulama yakni Wahid Hasyim dan Solehah. Memiliki satu Istri (Sinta Nuriyah) dan tiga putri. Pernah menempuh pendidikan di Pesantren Tembok Beras Jombang (1959-1963), Departemen studi Islam dan Arab Tingkat Tinggi, Universitas Al-Azhar, Kairo Mesir 1964-1966, Fakultas Surat-surat Universitas Bagdad 1966-2001, Pengajar di Pesantren, dekan Universitas Hasim Ashari, Fakultas Ushuluddin cabang teologi menyangkut hukum dan filsafat, Ketua Umum NU 19841999, Front Demokrasi (1990), Ketua Konferensi Agama dan Perdamaian Sedunia (1994), Anggota MPR (1999), Presiden RI 20 Oktober 1999-24 Juli 2001.

${ }^{15}$ M Dawam Rahardjo, Pembaruan KH Abdurrahman Wahid, dalam Kompas, Kolom Opini, 19 Januari 2007. 
melainkan dari keadilan Tuhan yakni perbuatan yang sesuai dengan azas Sunatullah. Apa yang diperbuat oleh manusia bukan untuk Tuhan (karena Ia tak butuh), melainkan akan kembali kepada diri manusia sendiri. Sangat berbeda dengan doktrin ajaran Katolik. Tradisi Katolik sangat percaya bahwa Tuhan Yesus akan menebus segala dosa yang dilakukan umat-Nya meskipun umat tersebut melakukan dosa sebesar apapun, karena kasih Yesus meliputi dunia seisinya. Apa tah lagi dalam kelompok Katolik ortodoks meyakini bahwa kasih Tuhan Yesus meliputi segala apa yang terjadi sebelumsementara-sesudah manusia berbuat.

Konsep ketuhanan Katolik, meyakini Tuhan sebagai pemilik dan penguasa sebelum hingga sesudah manusia berbuat, erat kaitannya dengan konsep ketuhanan dalam Islam, sebagaimana firman Allah yang erat kaitannya dengan kekuasaan Allah swt meliputi yang awal, akhir, yang nampak yang gaib dan meliputi segala sesuatu. Hal ini pula terdapat dalam QS Al-Hasyr (59):22.

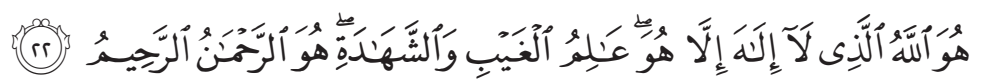

Dialah Allah yang tiada Tuhan selain Dia, yang mengetahui yang ghaib dan yang nyata, Dia-lah yang Maha Pemurah lagi Maha Penyayang. (QS.59:22)

Ayat di atas menjelaskan bahwa pengetahuan dan kekuasaan Allah meliputi seluruh mahluk-Nya, dengan demikian seseorang hamba yang memperoleh keselamatan harus mengikuti perintah dan menjauhi larangan-Nya.

\section{E. Esoterisme aksiologis}

Secara filosofi bahwa keselamatan manusia sangat ditentukan oleh manusia sendiri. Persoalan ini dapat terjadi, jika eksistensi manusia dapat ditingkatkan menjadi mengada, baik dalam kaitannya dengan vertikal maupun horisontal yang berkaitan dengan humanismenya. Permasalahan ini sangat relevan dengan hakikat manusia, sehingga hampir semua orang bijak memandang bahwa hakikat manusia merupakan esensi kehidupan dan kediriannya. Pandangan seperti ini telah muncul sejak munculnya filsafat Yunani kuno (Socrates, Plato, Aristoteles). 
Secara umum pandangan filosofi tentang eksistensi manusia terdiri atas tiga entitas yaitu corpus (jisim, tubuh), animus (nafs, jiwa), dan spiritus (ruh). Corpus kemudian ditransliterasikan menjadi corporeal (terkadang corporal) adalah material yang terdiri atas matter (materi mati) serta memiliki dimensi fisik. Ia merupakan satu aspek badaniah dari manusia (body, tubuh) yang berbeda dengan spiritus (spirit atau ruh) dan animus (soul atau nafs, jiwa). ${ }^{16}$

Animus, dari bahasa Yunani yaitu anemos artinya sesuatu yang meniup atau sesuatu yang bernafas. ${ }^{17}$ Plato berpendapat bahwa animus (nafs, jiwa) adalah penjelmaan wujud spiritual yang bisa mengada secara independen dari materi dan segala sesuatu yang terdefinisikan, dan ia adalah inti kedirian manusia, atau kesadaran yang nyata. Sedangkan spiritus -yang juga berarti 'angin', memiliki kesamaan arti dengan kata ruh (Bahasa Arab) yang artinya juga angin-menunjuk kepada sesuatu yang merupakan nafas kehidupan, kausa hidup yang dipahami sebagai uap halus atau udara yang menghidupkan organisme.

Dalam manusia spiritus atau ruh adalah entitas yang ada dalam jisim dan nafs. Oleh karena itu, kesenangan yang dirasakan manusia dan keselamatan yang diraihnya, lebih terpenting pada perasaan yang dirasakan oleh spiritus kemudian animus dan lebih lengkap lagijika perasaan ketenangan itu kepada corpus. Bagi kalangan filosof idealis memandang bahwa ketenangan dan keselamatan yang dirasakan setiap manusia dalam usahanya dirasakan oleh spiritus. Sedangkan bagi kalangan filosof materialis memandang bahwa keselamatan seseorang bukan saja dirasakan oleh spiritusnya tapi dirasakan semua unsur dalam diri manusia yakni corpus-animus dan spiritus.

Ketiga filosof tersebut sepakat bahwa hakikat kehidupan manusia ditujukan untuk menemukan eudaimonia -istilah yang dipakai oleh Aristoteles-yang bermakna kesejahteraan spiritualyang vital. Socrates menggunakan istilah daimon untuk hal tersebut yang dirujukkan sebagai suara batin yang digambarkan sebagai ruh yang

${ }^{16}$ Adlin, Alfathri dan Iwan S.; "Reduksi Konsepsi Manusia: Tinjauan Umum pada Era Pramodernisme, Modernisme dan Posmodernisme" dalam Journal of Psyche, vol. 1, Pusat Riset Metodologi dan Pengembangan Psikologi Yayasan Pendidikan Paramartha, Bandung, 2000, h.22.

${ }^{17}$ Ibid. 
ada di kuping telinganya. Daimon tersebut yang mengingatkannya tentang kebijakan dan kebajikan, melarangnya dari berbuat jahat. Daimon atau eudaimonia sering digunakan bergantian dengan istilah theos, seorang dewa (malaikat).

Pandangan filosofis di atas tentang puncak keselamatan yang dirasakan manusia sangat erat kaitannya dengan pandangan Islam yakni (keselamatan jasmani dan rohaniyah). Jadi keselamatan pada dasarnya bukan keselamatan materi saja, tapi lebih daripada itu yakni usaha maksimal manusia melakukan pencarian dan penemuan diri yang sejati, yaitu ketika seseorang dibimbing oleh daimon-nya dapat mengantarkan manusia untuk menemukan aretenya. Arete, dari bahasa Yunani berarti sesuatu yang baik dan unggul, dalam literatur Yunani, bila diterapkan pada seseorang, arete mengungkapkan kualitas-kualitas seperti keberanian, kegagahan, dan kekuatan. Dalam pengertian moral ia berarti keluhuran, kemanfaatan, dan kebaikan dalam memberikan pelayanan dan sering juga diterjemahkan sebagai kebajikan (virtue).

Adapun kebaikan yang didapat dari arete adalah agathon, yang dalam bahasa Yunani berarti baik. Dalam Platonisme, ini adalah sebutan untuk bentuk kebaikan tertinggi, gagasan puncak. ${ }^{18}$ Konsep pencarian dan penemuan diri ini yang oleh Socrates diungkapkan dalam kalimat "Gnothi Se Authon" (Kenali dirimu sendiri).

Proses untuk sampai kepada pengenalan diri yang mengakar dan tinggi (kearifan puncak), harus melalui penyucian diri, baik melalui akal pikiran, maupun rasa. Dengan demikian, ketenangan yang menjadi target ideal manusia secara filosofis sedapat mungkin akan dapat dicapai.

Dalam doktrin Islam menyebutkan bahwa keselamatan yang dirasakan manusia adalah keselamatan lahir dan bathin sebagaimana firman Allah dalam Alqur'an Al-Nahal (16):32;

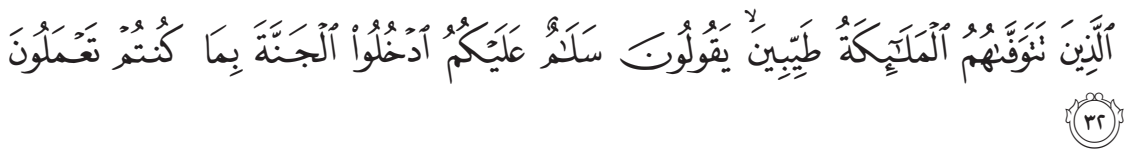

(yaitu) orang-orang yang diwafatkan dalam keadaan baik oleh para malaikat dengan mengatakan (kepada mereka):

${ }^{18}$ Ibid. h., 26. 
"Salaamun`alaikum, masuklah kamu ke dalam surga itu disebabkan apa yang telah kamu kerjakan”. (QS.16:32).

Relevansinya dengan ayat di atas, Muhammad Abduh ${ }^{19}$, mengatakan bahwa keselamatan terdiri dari keselamatan dunia dan keselamatan akhirat. Ia memandang bentuk keselamatan sangat rasional. Keselamatan menurut Abduh, sangat tergantung dari upaya maksimal seorang hamba Allah dalam mengelola potensi jiwa yang ada dalam diri setiap manusia dan menjaga keseimbangan antara pribadi dengan sesama manusia dan alam semesta secara horisontal, dan menjaga hubungan vertikal dengan Tuhan Yang Maha Esa.

Perspektif Abduh tentang dunia sebagai ladang akhirat. ${ }^{20}$ Oleh karena itu, seseorang dalam menjalani aktivitas keduniaannya harus berdasarkan norma-norma agama yang dianutnya. Seseorang yang ingin mencapai keselamatan dunia, harus berbuat dan mengelola dunianya sesuai dengan norma atau aturan yang berlaku. Jika ia merasakan selamat di dunia, maka kenikmatan lahir bathin senantiasa eksis dalam dirinya. Kenikmatan ini diidentikkan dengan surga dunia.

Konsep surga perspektif Abduh, bukan surga yang bersifat bendawi atau simbol-simbol tetapi surga tertinggi adalah puncak perjumpaan hamba dengan Tuhannya. Sedangkan neraka baginya adalah ketidak mampuan manusia mencari cahaya kebenaran dan cahaya Tuhan. Neraka tertinggi adalah kegelisahan manusia secara terus menerus, karena tidak dapat melihat Tuhannya. Karena itu ia kotor dan tidak mampu melihat cahaya kebenaran. ${ }^{21}$

Balasankebaikandiakhiratkelak, Tuhanakanmenyelamatkan dalam bentuk syafa'ah-Nya melalui Rasulullah saw. Beberapa dalil

${ }^{19}$ Ia lahir di Mesir sekitar tahun 1849 dan wafat di Kairo pada tahun 1905. Ibunya berasal dari suku Arab asli dan masih keturunan dari Umar bin Khatab, sedangkan ayahnya Hasan Khairullah, berasal dari Turki dan sudah lama tinggal di Mesir. Abduh pernah kuliah di Universitas al-Azhar Kairo memperoleh predikat baik dengan gelar Alim, di sini Abduh ketemu Jamaluddin al-Afgani. Beberapa tahun kemudian Abduh diangkat sebagai tenaga pengajar di al-Azhar untuk mengajarkan buku-buku Ibn Miskawaih dan Ibn Khaldun. Ia juga aktif di dunia politik, sebagai bukti ia menulis sebuah buku Al-Islām Din al-Ilmu wa al-Madaniyah. Lihat Harun Nasution, Pembaruan dalam Islam: Sejarah Pemikiran dan Gerakan, (Jakarta: Bulan Bintang, 1992), h. 62.

${ }^{20}$ Lihat, Ibid.

${ }^{21}$ Ibid. 
yang menjelaskan tentang syafa'at Nabi Muhammad saw kepada umatnya di akhirat antara lain;

Pertama, Hai nabi, sesungguhnya Kami mengutusmu untuk jadi saksi, dan pemberi kabar gembira dan peringatan. Menjadi penyeru kepada agama Allah dengan Izin-Nya dan untukmenjadi "cahaya yang menerangi”. Dan sampaikanlah kabar gembira kepada orang-orang yang beriman bahwa sesungguhnya bagi mereka karunia yang besar dari Allah. (Dan ingatlah) akan hari (ketika) Kami, bangkitkan pada tiap-tiap umat seorang saksi atas mereka dari mereka sendiri, dan Kami datangkan kamu (Muhammad) menjadi saksi atas seluruh umat manusia. Dan Kami turunkan kepadamu al-qur'an untuk menjelaskan segala sesuatu dan petunjuk serta rahmat dan kabar gembira bagi orang-orang yang berserah diri. (QS. al-Ahzab: 45-47).

Kedua, Muhammad itu sekali-kali bukanlah bapak dari seorang laki-laki di antara kamu. Tetapi dia adalah Rasulullah dan penutup para Nabi. Dan adalah Allah Maha Mengetahui segala sesuatu. (QS. al-Ahzab: 40), dan Allah swt. Berfirman; "Tidaklah Kami mengutusmu kecuali untuk menjadi rahmat bagi semesta alam”. (QS. al-Anbiya': 40).

Ketiga, di dalam hadis Rasulullah saw. bersabda: (1) Saya adalah Nabi yang paling banyak pengikutnya pada hari Kiamat, dan saya yang pertama kali akan mengetuk pintu surga. (HR. Muslim). (2) Rasulullah saw bersabda; Saya yang pertama kali akan memberi syafaat ke surga, belum pernah di benarkan salah seorang dari para Nabi seperti dibenarkannya saya. Hal ini ditegaskan dalam firman Allah:

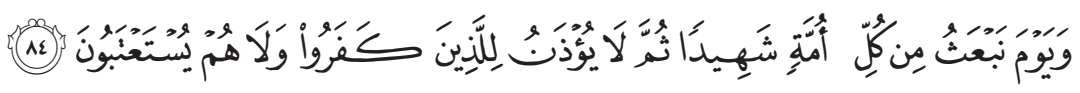

(Dan ingatlah) akan hari (ketika) Kami, bangkitkan pada tiaptiap umat seorang saksi atas mereka dari mereka sendiri, dan Kami datangkan kamu (Muhammad) menjadi saksi atas seluruh umat manusia. Dan Kami turunkan kepadamu Al Kitab (Al Qur'an) untuk menjelaskan segala sesuatu dan petunjuk serta rahmat dan kabar gembira bagi orang-orang yang berserah diri. (QS.16:84).

Dan sesungguhnya ada seorang dari para Nabi yang tidak dibenarkan umatnya kecuali hanya seorang saja (dari mereka) ${ }^{22}$. (3)

${ }^{22}$ Muhammad bin Jamil Zainu, Mengenal Kesempurnaan Rasul, cet; 1, 
Rasulullah saw bersabda yang artinya: Saya memohon kepada Allah tiga perkara. Dia mengabulkan dua di antaranya dan menolak yang lain. Saya memohon kepada-Nya agar umat saya tidak dibinasakan dengan paceklik, maka Allah mengabulkannya. Lalu saya memohon kepada-Nya agar umat saya tidak dibinasakan dengan tenggelam, maka Dia mengabulkannya. Dan saya memohon kepada-Nya agar tidak menjadikan bencana di antara mereka, maka Dia menolaknya. (HR. Muslim). (4) Dalam riwayat lain Rasulullah saw bersabada: Saya memohon kepada Allah agar musuh tidak menguasai umatku, maka Dia mengabulkannya. (HR. At Tirmidzi \& An Nasa`i, dishahihkan oleh Al-Bani). (5) Berkata Anas bin Malik ra. dalam hadits tentang Isra Mi raj, diantaranya: Dan kedua belah mata Nabi Muhammad saw tidur, akan tetapi hatinya tidaklah tidur. (HR. Muslim). (6) Rasulullah saw bersabda: Saya adalah pemimpin anak Adam pada hari Kiamat, saya yang pertama kali dikeluarkan dari kubur, yang pertama kali memberi syafa'at dan yang pertama kali diberi hak untuk memberi syafa'at. (HR. Muslim). (7) Rasulullah saw bersabda yang artinya: Saya diberi keutamaan atas para nabi dengan enam perkara: Saya diberi Jawami'ul Kalim, saya ditolong dari ketakutan, dihalalkan bagi saya rampasan perang, bumi dijadikan untuk saya sebagai masjid dan tempat yang suci, saya diutus kepada semua makhluk, dan saya sebagai penutup para nabi. (HR. Muslim). ${ }^{23}$ (8) Rasulullah saw: Saya diutus dari generasi terbaik anak Adam dari generasi-generasi, sampai saya berasal dari generasi yang saya berasal darinya. (HR. Bukhari).

Keempat, Rasulullah saw bersabda yang artinya: Sesungguhnya perumpaan saya jika dibandingkan dengan para Nabi sebelum saya adalah seperti seorang laki-laki yang membangun sebuah gedung, dia memperbagus dan mempercantik gedung tersebut, kecuali tempat bata merah yang terletak di pojok bangunan. Manusia mengelilingi bangunan itu dan kagum daripadanya. Mereka berkata: Alangkah sempurnanya bila diletakkan bata merah ini. Beliau berkata: Akulah bata merah itu, dan saya adalah penutup para nabi. Selain itu, Rasulullah saw bersabda yang artinya: Sesungguhnya di sisi Allah, saya ditetapkan sebagai penutup para Nabi, dan bahwasanya Adam sungguh dilemparkan di muka bumi.

(Madinah:Yayasan Al-Madinah 1999 M./ Shafar 1419 H.), h.17-22.

${ }^{23} \mathrm{Ibid}$. 
Saya akan memberi tahu kalian tentang urusan saya yang pertama kali, yaitu: Dakwahnya Nabi Ibrahim, berita gembiranya Isa, dan mimpi Ibu saya yang dilihatnya ketika melahirkan saya, telah keluar darinya cahaya yang menerangi istana Syam. (Dishahihkan oleh al-Hakim dan disetujui oleh al-Ahabi, dan dishahihkan al-bani di Misykah).

Sebuah kisah mengenai syafa'at Rasulullah saw sebagai berikut "Malaikat Jibril mendatangi saw. ketika beliau berada di Gua Hira`. Dia berkata: Iqra` bi ismi Rabbika allaz̧i khalaq (Al `Alaq:1). Maka pulanglah Rasulullah saw dengan hati yang bergetar. Beliau menemui istrinya Khadijah binti Khuwailid dan menceritakan kejadian yang dialaminya. Beliau berkata: Saya cemas, Khadijah menjawab:Sekali-kali tidak, Demi Allah, Dia tidak akan menghinakan kamu selama-lamanya. Karena kamu suka menyambung tali silaturrahmi, menanggung anak yatim, memberi pekerjaan kepada yang membutuhkan, memberi makan tamu, dan membantu wakilwakil kebenaran. Kemudian Khadijah pergi bersama Rasulullah saw ke rumah Waraqah bin Naufal. Berkata Khadijah: wahai anak pamanku, dengarkan apa yang akan dikatakan oleh anak saudaramu ini! Lalu Rasulullah saw menceritakan apa yang dilihatnya. Waraqah berkata: Ini adalah Namus (Jibril) yang telah diturunkan Allah kepada Musa. Duhai kiranya aku masih bisa bertahan, kiranya aku masih hidup ketika kaummu mengusirmu, Rasulullah saw berkata: Apakah mereka akan mengusir saya? Dia menjawab: Ya, tidaklah seseorang datang membawa sesuatu seperti yang kau bawa kecuali akan dimusuhi. Kalau saya masih bisa menjumpai hari-harimu itu maka saya akan menolongmu dengan pertolongan yang besar. (HR. Bukhari di Kitab Bad ’ul Wahyi). ${ }^{24}$

Kisah di atas, menggambarkan bahwa Muhammad saw adalah utusan Allah swt sebagai penolong besar kepada semua umat bahkan menjadi rahmat bagi alam semesta, dengan demikian untuk memperoleh syafa'at Rasulullah saw adalah menjalankan segala apa yang diucapkan, meneladani segala tindakan kenabian dan ketetapan yang telah diperintahkan Allah swt.

Konsep Katolik pun membenarkan eksistensi gembala di akhirat sana yang akan mendapat pembersihan dari Roh Kudus.

${ }^{24}$ Ibid. 
Rahmat Roh Kudus mempunyai kekuatan untuk membenarkan umat, artinya untuk membersihkan pengikutnya dari dosa dan untuk memberikan kepada para "pengembala" kebenaran Allah karena iman dalam Yesus Kristus dan karena pembaptisan (Rum 6:3-4).

"Jika kita telah mati dengan Kristus, kita percaya, bahwa kita akan hidup juga dengan Dia. Karena kita tahu, bahwa Kristus, sesudah Ia bangkit dari antara orang-orang mati, tidak mati lagi, maut tidak berkuasa lagi atas Dia. Sebab kematianNya adalah kematian terhadap dosa, satu kali dan untuk selama-lamanya, dan kehidupan-Nya adalah kehidupan bagi Allah. Demikianlah hendaknya kamu memandangnya; bahwa kamu telah mati bagi dosa, tetapi kamu hidup bagi Allah dalam Kristus Yesus" (Rum 6:8-11).

Secara teleologis surat di atas menggambarkan bahwa karena kuasa Roh Kudus manusia mengambil bagian dalam sengsara dan kebangkitan Kristus dengan mati terhadap dosa, dan dilahirkan dalam hidup baru (bdk.1 Kor 12). Merekalah ranting-ranting yang tinggal pada pokok anggur, yaitu Ia sendiri. (bdk Yoh 15:1-4.).

Secara bahasa dan substansial, konsep keselamatan dalam Islam dan Katolik terdapat kesamaan yang signifikan, sebab secara epistemologis sama-sama berasal dari satu rumpun bahasa yang sama. Perbedaannya hanya metodologi dan proses untuk menuju keselamatan itu sendiri. Dalam Islam terjadi berbagai pendapat antara lain: Pertama bahwa keselamatan baik di dunia maupun di akhirat sangat tergantung dari perbuatan seseorang. Jika seseorang melakukan sesuatu perbuatan yang mengandung nilai, maka balasannya sesuai dengan apa yang diperbuatnya. Persoalan seperti ini Mu'tazilah sebagai teologi rasional dalam Islam, memandangnya sebagai keadilan Tuhan. Kedua, perbuatan seseorang bukan indikator keselamatan yang diperolehnya, tetapi sangat ditentukan oleh takdir Tuhan. Seseorang yang kurang amalnya memungkinkan ia mendapat keselamatan, sebab ia telah mendapat rahmat dari Tuhan untuk selamat. Masalah konsep rahmat dan keadilan Tuhan yang berkaitan dengan keselamatan tersebut, perspektif teologi Asy'ariyah mengatakan bahwa keselamatan seseorang hamba baik di dunia maupun di akhirat merupakan intervensi Tuhan dari aspek rahmat dan rahimNya, karena itu, Dialah yang menentukan segala sesuatu. Prinsip teologi Asy'ariyah adalah “Apabila Allah menghendaki 
sesuatu, maka tidak ada unsur lain yang dapat menghalanginya”. Hal ini senada dengan firman Allah swt yang artinya "barang siapa yang dihinakan Allah, maka tidak ada seseorangpun yang memuliakannya. Sesungguhnya Allah menghendak/berbuat atasi segala sesuatu".

Masalah keselamatan dunia dalam perspektif Katolik, sangat tergantung dari kasih Tuhan kepada setiap manusia. Pandangan ini bersumber dalam al-Kitab, dan dirumuskan oleh Gereja dalam Konsili Vatikan II yang bertujuan memperbaharui berbagai adagium klasik. Ditegaskan bahwa keselamatan Tuhan berlaku secara universal. Semua manusia dipanggil untuk mencapai keselamatan itu. Tuhan pencipta langit dan bumi bukan hanya milik golongan tertentu, tetapi milik semua umat manusia dan segala mahluk. Dengan demikian sebagai bagian dari dunia, Gereja tetap terbuka untuk kerja sama dengan semua pihak untuk mencapai keselamatan universal itu. ${ }^{25}$

Bukti nyata keterbukaan Gereja terhadap semua agama di dunia terutama berpusat di Roma adalah adanya keterbukaan mereka terhadap non Katolik untuk bebas mengekspresikan agamanya masing-masing. Berdirinya Masjid dan tempat-tempat ibadat lain di Roma mencerminkan pengakuan akan eksitensi dan partispatif agama lain dalam kehidupan bermasyarakat di tengah-tengah dunia yang sedang membangun. Bahkan dalam dokumen-dokumen resmi Konsili Vatikan II dan seruan kepausan berkenan dengan hari-hari dewasa ini sungguh menghargai kehadiran agama-agama bukan Katolik dalam kehidupan bersama sebagai umat manusia dan makhluk Tuhan.

Berbeda halnya dengan sebagian kalangan Katolik yang mempunyai pemahaman eksklusif bahkan cenderung fundamental. Mereka menganggap bahwa agama di luar Katolik tidak diberkati bahkan sesat. Kalangan eksklusif ini meyakini bahwa hanya ada satu agama yang benar dan selamat, yakni Katolik. Oleh karena itu, di

${ }^{25}$ Keterbukaan eklesial ini menunjukkan bahwa Gereja sungguh membaca, menyelami dan menanggapi tanda-tanda zaman dewasa ini. Hal ini dijelaskan dalam karya refleksi teologis Jacques Dupuis (Universitas Gregoriana-Roma), Hans Küng (Jerman) dan Julia Ching (Canada) bahwa Gereja menunjukkan semakin membuka diri, Lihat William Chang, Dari "SARA" Menuju Teologi Agama-agama dalam Th.Sumartana, dkk, Pluralisme, Konflik dan Pendidikan Agama di Indonesia, cet; I (Yogyakarta: Institut DIAN/Interfedei, 2001), h.123-124. 
dalam tradisi Katolik, dikenal doktrin infalibilitas/infallibility, yang menyatakan bahwa Gereja bebas dari kemungkinan sesat dalam halhal yang berkaitan dengan iman dan kesusilaan yang diwahyukan. Sifat ini dianugerahkan kepada seluruh Gereja dengan perantaraan Roh Kudus, khususnya kepada Dewan Uskup dalam kesatuan dengan Paus, pengganti Petrus. Konsili Vatikan I (1869-1870) mengajarkan bahwa Paus tidak dapat sesat kalau sebagai gembala seluruh orang Kristiani dan pengganti Petrus.

\section{F. Kehadiran Yesus Sebagai Mitra Muhammad saw Penunjuk Keselamatan}

Doktrin keselamatan dalam Islam dan Katolik memiliki kemiripan. Kedua agama ini, mejelaskan bahwa sumber utama keselamatan adalah Allah. Keselamatan individual sangat relevan dengan eksistensi keselamatan kolektif. Keselamatan yang terbaik adalah keselamatan yang dimiliki secara individual dan kolektif. Kaitannya dengan keselamatan individual, bahwa salah satu cara untuk memperoleh ridha Allah dalam hidup, membebaskan hati untuk meraih ridha Allah. Karena ridha Allah sangat tergantung kepada ridhanya manusia dan lingkungan alam sekitarnya. Ridha yang dimaksud adalah seseorang mampu menjaga keseimbangan antara pribadi, orang lain dengan lingkungan alam sekitarnya.

Jalan-jalan untuk mencapai keselamatan dalam ajaran Katolik adalah melakukan pengorbanan yang maksimal, sebagaimana cara Yesus dalam menjalani pengorbanan yang dilakukan oleh Yesus ${ }^{26} \mathrm{di}$ tiang salibnya. Dari peristiwa penyaliban ini mengandung hikmah yang harus dipetik oleh kalangan Kristiani, yaitu menarik hikmah dari peringatan wafatnya Yesus. Inti dari hikmah yang Jumat Agung ini adalah bagaimana umat Kristiani melakukan pengorbanan kepada sesama, tanpa memandang suku, agama dan keturunan. ${ }^{27}$ Dalam kepercayaan Katolik bahwa hari Paskah adalah hari yang

${ }^{26}$ Sang Putra Allah menerimanya dengan ikhlas demi menyelamatkan umat yang banyak. Kata Pendeta Daniel Sopamena M.Th, meninggalnya Yesus Kristus dengan cara disalib , merupakan pengorbanan mulia untuk menebus dosadosa manusia.

${ }^{27}$ Petikan wawancara Khusus reporter Fajar dengan ketua PGIW Makassar Pendeta Daniel Sopamena, M.Th. dalam rangka peringatan hari Jumat Agung, Harian Fajar Jumat tanggal 14 April 2006. 
sangat sakral serta memiliki hikmah yang dapat dipetik oleh umat Kristiani dalam kehidupan sehari-hari. Di hari Paska Yesus Kristus yang disalib dengan pengorbanan tertinggi bangkit dari kematian. Pengorbanan itu semata-mata demi penebusan dosa sang umatnya. Dengan demikian paska bagi umat Kristiani merupakan momen tepat untuk meningkatkan pengorbanan dalam berbagai bentuk terhadap sesama manusia dengan tanpa pilih kasih guna membangun masyarakat yang toleran.

Membangun masyarakat-terutama masyarakat post-modernterutama pada wilayah toleransi merupakan upaya hidup bersama dalam rahim dunia sebagai simbol kasih sayang diantara sesama manusia tanpa membedakan satu dengan yang lain. Perbedaan yang tampak pada seseorang bukan merupakan perbedaan, tetapi bagian dari pluralitas kehidupan yang sangat indah.

Masyarakat post-modern adalah masyarakat yang menurut AlfinToflersebagai “futureshock"sebagianbesartelahberkecenderungan ke arah situasi keterasingan atau teralienasi, yang sedikit dapat dibedakan setidaknya ada tiga kelompok. Pertama, mereka yang teralienasikan dari Tuhannya, yang disebabkan terutama oleh prestasi sains dan teknologi, sehingga menjadi positivistik. Kedua, mereka yang mengalami keterasingan dari lingkungan sosialnya. Ketiga, mereka yang terasing dari Tuhannya sekaligus juga dari lingkungan sosialnya. ${ }^{28}$

Manusia post-modern yang digambarkan di atas akan mengalami kekeringan spiritual dan keterpisahan dengan nilainilai ilahiyat, jika menjadikan hal-hal yang materialistik sebagai tujuan. Sebaliknya mereka akan menjadi mandataris Tuhan di bumi ini apabila segala aspek kehidupan mampu melekatkan dan mengimanenkan nilai-nilai ketuhanan di dalam dirinya. Jika demikian, maka mereka berprinsip bahwa bukan materi atau simbolik sebagai tujuan hidup, melainkan Tuhan Yang Maha Agung.

${ }^{28}$ Kelompok-kelompok tersebut telah menegasikan realitas metafisis dan menganggapnya sebagai realitas semu, karena cara pandangnya sangat positivissaintisme. Pandangan ini tentunya sangat beda jauh dengan paradigma orang yang beriman yang berkeyakinan bahwa realitas materi yang kasad mata adalah derivasi dari Realitas Tertinggi (Ultimate Reality). Lihat, Komaruddin Hidayat, Psikologi Kematian; Mengubah Ketakutan Menjadi Optimisme (Cet.1; Jakarta: Hikmah, 2005), h.3233. 
Untuk merealisasikan nilai-nilai ketuhanan dalam diri setiap insan post modern, maka kesadaran akan omnipresent (kemaha hadiran Tuhan) sangat diidamkan.

Seseorang yang merasakan kemaha hadiran Tuhan di dalam dirinya, dengan sendirinya akan memberikan kekuatan, pengendalian (limited desire) sekaligus keselamatan hati seseorang, sehingga yang bersangkutan senantiasa merasa berada dalam orbit Tuhan $^{29}$, bukannya putaran dunia yang tak jelas lagi pangkalnya.

Manusia sebagai pengemban ajaran suci Tuhan merupakan mediator yang menghubungkan tali persaudaraan yang suci demi mencapai keselamatan khususnya di dunia. Ajaran Katolik mengajarkan bahwa dalam rangka mengembangkan misi keselamatan dan keselamatan baik antara intern Katolik maupun ekstern hubungan antar iman diperlukan dan dirasakan pentingnya dialog. Dialog keselamatan merupakan wujud dialog Gereja yang dimulai secara spontan atas inisiatif Allah. Dialog keselamatan lahir dari kasih dan belas kasihan Allah karena, "begitu besar kasih Allah akan dunia, sehingga Ia telah mengaruniakan Anak-Nya yang tunggal (Yoh 3:16). Karena Allah mencintai kita terlebih dahulu (1Yoh 4:10), maka adalah kewajiban kita untuk mengambil langkah pertama dalam menjalin dialog dengan manusia dan janganlah menunggu diundang untuk itu. ${ }^{30}$ Dengan berdialog maka akan membuka hubungan kasih dengan sesama mahluk Tuhan. Tuhan telah mencintai semua makhluknya maka manusia wajib untuk saling bercinta kasih di antaranya baik sesama agama maupun beda agama. Hal ini juga telah dinyatakan dalam doktrin Islam bahwa orang-orang yang selamat adalah orang senantiasa menyambung silaturrahim di antara sesamanya. Karena dengan ber-silaturrahim manusia akan saling mengerti tentang kekurangan dan kelebihan dirinya dan orang lain, sehingga dari sinilah awal persahabatan yang mulia.

${ }^{29}$ Beberapa upaya untuk menyandarkan diri dalam orbit Tuhan adalah takhaluq,(usaha untuk mengikuti sifat-sisat Tuhan) ta'aluq (mencerminkan sifat Tuhan dalam kehidupan) dan takhaquq (Berbuat sesuai dengan akhlak Allah).

${ }^{30}$ Pernyataan Paus Paulus VI tegas dan jelas untuk mengambil inisiatif dialog sebab Allah telah lebih dahulu mengambil inisiatif karya penyelamatan. Lihat, FX.E.Armada Riyanto, CM. Dialog Agama Dalam Pandangan Gereja Katolik, (Yogyakarta: Kanisius, 1995), h. 38-39. 
Dialog seperti ini mengurangi prasangka yang negatif antara penganut Islam dan Katolik khususnya, dan agama lain pada umumnya. Sebagai pemimpin Gereja Anglikan seluruh dunia William ${ }^{31}$ mengingatkan, "Jika kita ingin membujuk kelompok Muslim moderat untuk hidup saling toleran, serta mengakui pluralisme beragama, maka tindakan apapun yang mengesankan bahwa memusuhi bahkan memburu kaum muslimin, akan menjadi problem untuk mencapai cita-cita kebersamaan. Tidak menutup kemungkinan akan banyak masalah yang muncul," sehingga sangat mempengaruhi tingkat keselamatan yang dirasakan oleh penganut kedua agama tersebut.

Perspektif Islam mengenai keselamatan sebagaimana terdapat dalam al-Qur'an:

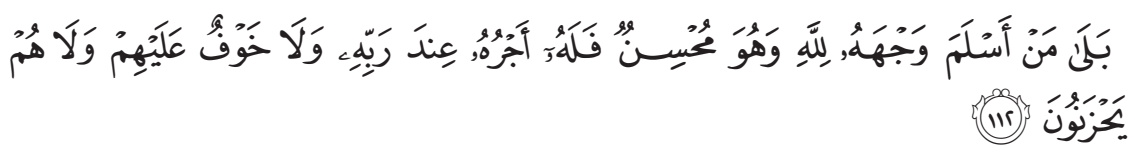

Bahkan barangsiapa yang menyerahkan diri kepada Allah, sedang ia berbuat kebajikan, maka baginya pahala pada sisi Tuhannya dan tidak ada kekhawatiran terhadap mereka dan tidak mereka bersedih hati (QS. Al-Baqarah [2]: 112).

Maksud ayat di atas, bentuk penyerahan diri dimaksud adalah cara beragama yang sesuai dengan tuntunan agama itu sendiri baik dalam bentuk pengabdian yang bersifat maghdah maupun ghairu maghdah. Meskipun ada juga yang memahaminya bahwa berserah diri yang dimaksud adalah ber-Islam yang benar. Beribadah sesuai dengan ketentuan yang berlaku dalam norma agama maka itu juga masuk pada kategori berbuat kebajikan dengan mengharapkan ridha Allah swt. Cara seperti ini merupakan kategori upaya mengharapkan keselamatan di dunia mapun diakhirat.

Berbuat kebajikan untuk kepentingan diri dan orang lain disertai dengan niat ikhlas maka akan mendapatkan keuntungan di dunia dan pahala di akhirat. Menurut ajaran Islam, seseorang yang berbuat kebaikan didunia dengan ikhlas dan mengharapkan ridha Allah swt, maka tiada keraguan bagi mereka. Tidak ada keraguan

${ }^{31}$ Williams dikenal sebagai pendeta yang selalu melakukan cara-cara dialog dengan kelompok Islam sebagai prioritas utama untuk memelihara hubungan kedua agama itu. 
maksud ayat di atas adalah Allah menjamin keselamatannya di dunia dan akhirat.

Sesungguhnya kebahagiaan pada negeri akhirat itu adalah bagian dari kenikmatan yang diperoleh di dunia, sebagaimana firman Allah swt:

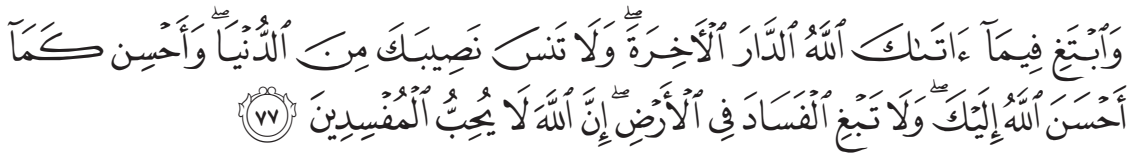

Dan carilah pada apa yang Telah dianugerahkan Allah kepadamu (kebahagiaan) negeri akhirat, dan janganlah kamu melupakan bahagianmu dari (kenikmatan) duniawi dan berbuat baiklah (kepada orang lain) sebagaimana Allah Telah berbuat baik, kepadamu, dan janganlah kamu berbuat kerusakan di (muka) bumi. Sesungguhnya Allah tidak menyukai orang-orang yang berbuat kerusakan.

Manusia dalam melakukan sesuatu perbuatan untuk meraih hasil, harus melaksanakannya sesuai ketentuan syariat agama harus disertai dengan doa. Doa di sini merupakan sebuah harapan yang tertinggi seorang hamba kepada Tuhannya. Para pendoa akan diterima doa-nya apabila mereka berdoa sesuai dengan ketentuan. Perintah berdoa di dalam ajaran Islam sangat jelas sebagaimana firman Allah dalam al-Qur'an:

"Berdoalah kepada Aku Niscaya Aku akan mengabulkannya”.

Doa menurut bahasa artinya minta, usaha sungguh-sungguh. Konteks doa dalam ayat tersebut, dapat digolongkan ke dalam doa yang bersifat khusus yakni doa sebagai ritual sebagaimana seseorang berdoa setelah melaksanakan shalat wajib, sahalat sunat, upacara-upacara ritual. Selain itu, doa juga dapat dipahami dalam pengertian luas yakni usaha sungguh-sungguh yang sesuai dengan hukum agama (sunatullah). Contoh seseorang yang ingin mendapatkan sertifikat dalam pelatihan, maka ia harus mengikuti aturan main (rule of game) dalam pelatihan tersebut termasuk tata tertib, kedisiplinan, keseriusan dalam mengikuti acara mulai dari awal hingga akhir. Kalau hanya mengandalkan doa dalam bentuk ritual, maka jangan berharap banyak untuk dikabulkan, sebab telah melanggar hukum Allah. 
Cara untuk mendapatkan keselamatan di dunia dan akhirat adalah dengan berdoa sebanyak-banyaknya. Doa yang lazim dan sederhana baik kelompok maupun sendiri-sendiri adalah doa rosario, rangkaian doa Bapa kami, "Salam Maria dan kemuliaan". Doa rosario terdiri dari 200 butiran "salam Maria" dengan menyebut Bapa kami. Sedangkan doa salam Maria sangat terkait dengan Ibu Maria sebagai Bunda Allah sebab beliaulah yang melahirkan Yesus.

Tujuan berdoa "Salam Maria" adalah untuk mendapatkan pengalaman iman terutama pengalaman Maria yang ditampaki Jibril. Melalui doa "Salam Maria" seorang beriman Katolik dapat berjumpa dengan Allah. ${ }^{32}$

Doa rosario adalah untaian peristiwa:

Pertama, peristiwa gembira ${ }^{33}$, ditandai dengan sukacita yang memancar dari peristiwa inkarnasi ${ }^{34}$ Ini jelas dari peristiwa pertama, Maria menerima kabar gembira dari malaikat Gabriel; di sini salam Gabriel kepada gadis Nazaret dikaitkan dengan wacana sukacita, "bersukacitalah, Maria." Seluruh sejarah keselamatan, dan dalam arti tertentu seluruh sejarah dunia, telah dituntun kepada salam ini. Sukacita juga mewarnai peristiwa kedua: Maria mengunjungi Elisabet, saudarinya. Dalam perjumpaan ini, suara Maria dan kehadiran Yesus dalam rahimnya membuat Yohanes "melonjak kegirangan". ${ }^{35}$

Kedua, rosario peristiwa terang, disini seseorang merenungkan peristiwa-peristiwa yang khusus disebut "peristiwa terang" sebagai misteri Kristus adalah misteri terang, karena Yesus adalah "terang dunia" (Yoh 8:12). Dalam untaian peristiwa terang ini, secara khusus

${ }^{32}$ Karena anggur kami habis dengan berdoa dengan cara salam Maria maka, Yesus dengan keenakan hati turunlah mukjizatnya dengan dapat teratasi (Yohanes:2), Mimbar agama Katolik dengan tema Do'a dalam ajaran Katolik yang dibawakan oleh Pastor Yustianus Ardianto, Pr. Hari Sabtu tanggal 6 Mei 2006 jam 09.00 Wib. Di TVRI.

${ }^{33}$ Bdk. RPM,no.20.

${ }^{34}$ Misteri ini mengantar pendoa memusatkan perhatian pada peristiwa inkarnasi yang membawa sukacita dan pada bayang-bayang kelam sengsara yang menyelamatkan. Pendoa dituntut menemukan rahasia sukacita Kristiani, sekaligus dingatkan bahwa agama Kristiani adalah euangelion (kabar baik) dan inti kabar baik adalah Yesus Kristus, sabda yang menajadi daging Juru Selamat dunia.

${ }^{35}$ Bdk. Luk 1:44. 
ditonjolkan lima peristiwa berikut: (1) Yesus dibaptis di sungai Yordan, (2) Yesus menyatakan diri-Nya dalam pesta perkawinan di Kana, (3) Yesus memberitakan Kerajaan Allah dan menyerukan pertobatan, (4) Yesus menampakkan kemuliaan-Nya, dan akhirnya (5) Yesus menetapkan Ekaristi.

Ketiga, Peristiwa sedih ${ }^{36}$, kesalehan Kristiani dipusatkan pada sengsara Kristus, karena di sinilah ditemukan puncak pewahyuan kasih Allah dan sumber keselamatan. Doa rosario memilih peristiwaperistiwa tertentu dari sengsara Kristus, sambil mengundang kaum beriman untuk merenungkannya dalam hati dan menghayatinya. ${ }^{37}$

Keempat, rosario peristiwa mulia, ${ }^{38}$ renungan tentang Kristus tidak bisa berhenti pada salib. Kristus yang mati di kayu salib itu telah bangkit ${ }^{39}$, pada tahap ini orang beriman dapat melintasi kegelapan sengsara untuk memandang kemuliaan Kristus dalam peristiwa, (1) Yesus bangkit di antara orang-orang mati, (2) Yesus naik ke surga, (3) Roh Kudus turun atas para rasul, (4) Maria diangkat ke surga (5) Maria dimahkotai di surga.

Selainitu, para penganutKatolikmengaplikasikan peringatanperingatan hari-hari besar agama Katolik selain sebagai wujud iman juga merupakan upaya mengambil hikmah dari perayaan tersebut. Salah satu dari perayaan yang mengandung dwi nilai adalah pesta paskah. Pesta paskah ini selain mengandung nilai sejarah juga merupakan nilai iman dan bentuk usaha penganut Katolik dalam meraih keselamatan. Untuk meraih keselamatan, penganut Katolik merayakan dengan hikmad yaitu sebuah pengharapan kepada Tuhan agar peristiwa suci ini dapat dipercikan kepada siapa yang dikehendakinya sebagaimana pengalaman yang diberikan Tuhan kepada Yesus.

${ }^{36}$ Bdk. RPM.no.22.

${ }^{37}$ Urutan renungan dimulai dengan peristiwa-peristiwa Getsemani: Yesus berdoa kepada BapaNya di surga dalam sakratulmaut; di sini Yesus mengalami sakratul maut menghadapi kehendak bapa,"bukanlah kehendak-Ku, melainkan kehendak-Mulah yang terjadi (Luk 22:42par.) Kata "ya” yang diucapkan Yesus ini kebalikan dari kata "tidak" dari leluhur pertama di taman eden.

${ }^{38} \mathrm{Bdk}$. RPM, no.23.

${ }^{39}$ Yohanes Paulus II, Surat Apostolik Novo Millenio Ineunte, 6 Januari 2001, h.28. 
Pesta Paskah $^{40}$ atau peringatan kebangkitan Isa Almasih, erat hubungannya dengan pesta Paskah Yahudi. Pesta Paskah Yahudi dirayakan pada malam 14 dan 15 dari bulan nisan. Asal mulanya pesta terang bulan atau lebih nyata pesta pertanian atau peternakan, dimana para petani mengorbankan roti yang terbuat dari gandum yang baru dipanen dari para gembala mengorbankan anak dombanya yang baru diperolehnya. Mungkin kebiasan upacara ini diwarisi dari penduduk asli dari Kanaan yang kafir. Kemudian bani Israil memberi arti lain atas pesta ini, arti tarikhi; peringatan keluarnya bani Israil dari Mesir, kira-kira 1230 sebelum Masehi.

Dari rentetan sejarah munculnya perayaan Paskah tersebut, maka menurut keputusan Konsili Nikea pada tahun 325 pesta bangkit harus dirayakan pada hari Ahad sesudah tanggal 14 nisan. Ini adalah sekalian pesta tahun baru yang dihubungkan dengan ciptaan dunia oleh Sang Putra Yesus. Pesta-pesta ini diperpendek hingga 3 hari. Jadi pesta Paskah jatuh pada hari Ahad pertama sesudah bulan purnama, secepat-cepatnya antara tanggal 22 Maret dan paling lambat 25 April.

Dalam perayaan Paskahini, para penganutKatolikmenjadikan sebagai momen terpenting bahkan hari yang sangat dikultuskan dalam rangka mencapai apa arti keselamatan dalam hidup. Sebab keselamatan dapat diperoleh dengan semangat pengorbanan yang tinggi, sebagaimana pengorbanan yang dilakonkan Yesus Kristus pada tiang salib.

Pengorbanan yang paling minimal adalah penganut Katolik akan memiliki kesalehan atau kesetiaan dalam beribadah. Dengan kesetiaan ini seseorang akan memperoleh keselamatan dari Tuhannya. Perayaan hari Paskah itu dimulai dengan trihari suci berturut-turut Kamis, Jumat dan Sabtu. ${ }^{41}$

${ }^{40}$ Bahasa Ibrani, Paskah, dari kata ini menjadi Pesakh, Paskah. Hal ini dapat dilihat dari upacara Yahudi di Bibel kitab Keluaran 12 dan 13 yang dirayakan sebagai pesta-perumahan di antara keluarga, sedangkan menurut kitab Ulangan 16 ayat 1-8 pengorbanan Paskah diadakan di tempat suci di bait-Allah di Yerusalem. Sesudah kota suci Yerusalem dibinasakan (586 SM) upacara korban ditiadakan, sedangkan upacara lain masih diadakan. Hanya sekta Samaritan yang melanjutkan upacara korban dan lain-lain secara tradisional di bukit Grezim. Lihat Koran Harian Fajar Komentar tentang Paskah tanggal 14 April 2006.

${ }^{41}$ Kamis Putih untuk mengenang saat terakhir Yesus hidup di dunia, Jumat 
Pengorbanan Yesus pada peristiwa ini, umat Katolik meningkatkan kesetiaan dalam beribadah dan menjalankan tugas yang diamanahkan Allah kepada umatnya. Umat Katolik harus mengorbankan hidup, sekalipun nyawa sebagai taruhannya. Dalam konteks kekinian makna wafat Yesus tersirat dalam solidaritas serta kesetiakawanan. Bagaimanapun umat Katolik mencintai Tuhannya, maka mencintai sesama manusia dan mahluk Tuhan tidak dapat diabaikan. Sebab hubungan vertikal manusia dengan Tuhannya sangat ditentukan oleh jalinan kasih manusia sesama manusia bahkan dengan segala mahluk ciptaan-Nya. Sifat seperti ini merupakan manifestasi Kasih Tuhan yang ber-tajalli di dalam diri seseorang.

Umat Islam tidak lantas merendahkan nabi-nabi yang datang sebelumnya, apalagi nabi-nabi yang disebut di dalam al-qur'an - Seperti Nabi Isa as. (Yesus) bukan merupakan nabi yang harus dinegasikan dalam keimanan muslim, tetapi harus dihormatinya. Sebab Yesus (bahasa Yunani) merupakan nabi yang memiliki sifat ilahiyat dan penampakkan Tuhan dalam cinta kasih-Nya. Di dalam diri Isa as terdapat percikan asma al-husnah-Nya dengan sifat jamaliyah Tuhan. Akan tetapi kesempurnaan Muhammad adalah di dalam dirinya terdapat kombinasi jamaliyah dan jalaliyah Tuhan.

Kesempurnaanyangterdapatdidalam dirinya, patutdicontohi oleh umat Islam dalam menuju keselamatan dunia akhirat, adalah mewujudkan segala ucapan, perbuatan dan ketetapan dalam hidup bermasyarakat. Karena itu, mencontohi Rasulullah merupakan upaya realisasi akhlak Tuhan dalam kehidupan sebagai mandatarisNya. Dengan tidak menegasikan kesempurnaan ciptaan Tuhan yang tertinggi pada diri Yesus, bahwa Muhammad mengandung nama dari semua nabi, sebagaimana terdapat dalam syair Mahmud Syabistari dengan menggunakan nama esoteriknya, Ahmad dalam kitabnya Guilsyan-I ra'az atau “Taman Rahasia Misteri Tuhan”. Karena jumlah ke100 telah datang, yang 99 menjadi milik kita. Sebutan Ahmad mengandung nama dari semua nabi. ${ }^{42}$

Agung hari kematianYesus yang tragis karena dibunuh. Sedangkan Sabtu persiapan kebangkitan Yesus, malam tirakatan atau malam berjaga, karena dia bangkit pada Minggu subuh hari.

${ }^{42}$ Sebagaian pendapat mengatakan bahwa sejumlah asma al-husna yang 
Hal yang sama sebutan Ahmad sebagai sifat yang terpuji, dapat ditemukan di dalam sifat jamaliyah-Nya di dalam diri Yesus, dan jalaiyah-Nya terdapat pada diri Musa as. Begitu pula sifat -sifat terpuji yang terdapat pada sejumlah nabi yang tercantum di dalam Alqur'an . Bahkan kepada nabi yang tidak dicantumkan dalam Alqur'an sekalipun, termasuk kelompok-kelompok orang-orang arif. Dengan perbuatan yang mulia merupakan aspek tingkah laku yang terpuji di sisi Tuhan dan di mata masyarakat. Sifat-sifat terpuji ini sangat pantas untuk diamalkan oleh kelompok muslim dan Katolik pada era sekarang, era multikutural dengan tujuan semata-mata dalam rangka menuju kehidupan yang penuh salam atau salom terutama damai dalam keragaman sosial budaya dalam kehidupan masyarakat Indonesia yang pluralis.

Secara aksiologis tentang upaya aktualisasi kehidupan selamat di antara sesama manusia yang berbeda keyakinan dan keragaman budaya, merupakan unsur keindahan hidup yang senantiasa dirindukan oleh semua orang. Hanya saja perlu diketahui semua unsur manusia, dalam meningkatkan kehidupan yang damai sejahtera, aman dan tentram harus selalu melakukan introspeksi diri pada setiap umat baik yang menyangkut tentang diri, kelompok sosial keagamaaan, maupun budaya masing-masing. Dalam tradisi tasawuf bahwa orang-orang yang senantiasa banyak melakukan introspeksi diri, maka mereka akan mendapatkan kearifan yang banyak. Dengan mengetahui kearifan maka ia selalu berbuat pada koridor "Akhlaq Allah".

Ajaran Katolik pun mengenal konsep kearifan manusia paripurna yakni manusia yang mendapatkan pembenaran melalui sengsara Kristus, yang menyerahkan diri di salib sebagai persembahan yang hidup, kudus dan berkenan kepada Allah dan darah-Nya telah menjadi alat pemulih bagi dosa semua manusia. Kebenaran

terdapat pada diri Tuhan, merupakan nama yang bertengger pada diri kenabian Muhammad. Sedangkan dalam perspektif Islam Muhammad memiliki beberapa nama secara sosiologis antara lain; Ahmad artinya yang paling terpuji di antara orang-orang yang memuji Allah, Abdullah adalah Hamba Allah, Abu al-Qāsim, artinya Bapak Qasim, dan al-Amin, artinya yang terpercaya. Begitu pula Muhammad kapan disebut maka disertai dengan ucapan "semoga kedamaian dan rahmat Allah atasnya. Lihat, Sayyed Hosein Nasr, The Heart of Islam: Pesan-pesan Universal untuk kemanusiaan, (cet. ke-1; Bandung: Mizan, 2003), h. 44-45. 
diberikan manusia dengan melalui pembatisan, Sakramen iman. Ia menjadikan manusia serupa dengan kebenaran Allah. ${ }^{43}$

Dengan demikian, keselamatan umat manusia menurut paham Katolik adalah bagian dari karya penyelamatan Allah dalan kasih-Nya. Dengan kasih Kristus maka apa pun yang dihadapi manusia di hari keabadian itu, melalui iman dan keselamatan Allah yang menyertai dirinya, maka keselamatan dan keselamatan yang abadi mereka rasakan. Sebaliknya jika seseorang tidak mendapatkan kasih Allah, maka ia tidak akan abadi bersama Kristus, sebab mereka tidak percaya akan ke-Allahan Dia.

\section{G. Penutup}

Beberapa uraian di atas dapat disimpulkan sebagai berikut; Pertama, Kehadiran dan kebenaran bukan pada Yesus atau Muhammad saw, tetapi kehadiran hanya sebatas penyampai dan peringatan bukan untuk menjadi Tuhan yang otoriter dan dipertuhankan oleh Umat, karena ia hanya pancaran dan perpanjangan tangan tuhan (agent of wisdom). Akan tetapi Kebenaran itu sendiri adalah bersumber dari pemberi kebenaran yakni Tuhan Allah swt atau dalam perspektif Katolik Ia adalah Elea Tuhan kita. Tulisan ini membahas tentang bagaimana titik sentuh secara aksiologi antara Katolik dengan Islam tentang keselamatan yang menjadi tujuan hidup manusia. Kedua, Secara aksiologis tentang upaya aktualisasi kehidupan selamat di antara sesama manusia yang berbeda keyakinan dan keragaman budaya, merupakan unsur keindahan hidup yang senantiasa dirindukan oleh semua orang. Ketiga, Hanya saja perlu diketahui semua unsur manusia, dalam meningkatkan kehidupan yang damai sejahtera, aman dan tentram harus selalu melakukan introspeksi diri pada setiap umat baik yang menyangkut tentang diri, kelompok sosial keagamaaan, maupun budaya masing-masing. []

${ }^{43}$ Tujuan pembenaran ialah kemuliaan Allah dan Kristus, demikian juga anugerah kehidupan abadi. Pembenaran mendasari kerja sama antara rahmat Allah dan kebebasan manusia. Ia terungkap dalam kenyataan manusia menerima sabda Allah. 


\section{Daftar Pustaka}

Departemen Agama RI, Al-Qur'an dan Terjemahannya, Semarang: Toha Putra, 1989.

Hidayat, Komaruddin, Psikologi Kematian; Mengubah Ketakutan Menjadi Optimisme, Jakarta: Hikmah, 2005, Cet.1.

Journal of Psyche, vol. 1, Pusat Riset Metodologi dan Pengembangan Psikologi Yayasan Pendidikan Paramartha, Bandung, 2000

Nasr, Sayyed Hosein, The Heart of Islam: Pesan-pesan Universal untuk kemanusiaan, Bandung :Mizan, 2003, cet. I.

Nasution, Harun, Pembaruan dalam Islam: Sejarah Pemikiran dan Gerakan, Jakarta: Bulan Bintang, 1992.

Paulus II, Yohanes, Surat Apostolik Novo Millenio Ineunte, 6 Januari 2001, p.28.

Rahardjo, M. Dawam, Pembaruan KH Abdurrahman Wahid, dalam Kompas, Kolom Opini, 19 Januari 2007.

Riyanto, FX.E. Armada, CM. Dialog Agama Dalam Pandangan Gereja Katolik, Yogyakarta: Kanisius, 1995.

Sumartana, Th., dkk, Pluralisme, Konflik dan Pendidikan Agama di Indonesia, Yogyakarta: Institut DIAN/Interfedei, 2001, cet; I.

Watt, William Montgomery, Titik Temu Islam dan Kristen Persepsi dan Salah Persepsi, Terj: Zaimudin, Jakarta: Penerbit Gaya Media Pratama, 1996, Cet. I.

Zainu, Muhammad bin Jamil, Mengenal Kesempurnaan Rasul, cet; 1, Madinah:Yayasan Al-Madinah 1999 M./ Shafar 1419 H. 